\title{
Hubungan Stunting dengan Perkembangan Motorik Kasar dan Halus Anak Usia 2-5 Tahun di Desa Panyirapan, Kecamatan Soreang Kabupaten Bandung
}

\author{
Citra Kartika, ${ }^{1}$ Yani Dewi Suryani, ${ }^{2}$ Herry Garna ${ }^{3}$ \\ ${ }^{1}$ Program Studi Pendidikan Dokter, ${ }^{2,3}$ Bagian Ilmu Kesehatan Anak \\ Fakultas Kedokteran, Universitas Islam Bandung
}

\begin{abstract}
Abstrak
Stunting adalah kondisi gizi kronik yang diakibatkan oleh pemberian nutrisi yang tidak seimbang dengan kebutuhan berdasar atas indeks panjang badan menurut usia dengan nilai melampaui <-2 Standar Deviasi (SD). Efek jangka pendek stunting salah satunya dapat memengaruhi perkembangan motorik. Stunting dan perkembangan motorik erat kaitannya dengan kuantitas dan kualitas nutrisi yang masih terbatas sehingga proses perkembangan saraf yang dibutuhkan untuk fungsi motorik menjadi terganggu. Penelitian ini bertujuan mengetahui hubungan stunting dengan perkembangan motorik kasar dan halus pada anak usia 2-5 tahun di Desa Panyirapan, Kec. Soreang, Kab. Bandung periode Agustus-September 2019. Penelitian ini merupakan analitik observasional menggunakan desain kasus kontrol dengan prosedur matching. Subjek dipilih menggunakan teknik pemilihan purposive sampling didapat sampel 37 anak untuk tiap kelompok kasus dan kontrol. Penilaian perkembangan motorik kasar dan halus menggunakan kuesioner praskrining perkembangan aspek motorik kasar dan halus. Data status stunting didapat berdasar atas skor-z indeks tinggi badan menurut usia kurang dari -2 SD. Analisis data menggunakan Uji Mc. Nemar. Hasil uji diperoleh status gizi stunting kemungkinan 5,02 kali (IK 95\%: 1,46-17,21) mengalami suspek gangguan perkembangan motorik kasar $(\mathrm{p}=0,013)$ serta kemungkinan 6,28 kali (IK 95\%: 1,85-21,39) mengalami suspek gangguan perkembangan motorik halus dibanding dengan status gizi tidak stunting $(\mathrm{p}=0,012)$. Simpulan, terdapat hubungan stunting dengan perkembangan motorik kasar dan halus pada anak usia 2-5 tahun.
\end{abstract}

Kata kunci: Anak, KPSP, motorik halus, motorik kasar, stunting

\section{Correlation between Stunting with Gross and Fine Motor Development of Children Aged 2-5 Years Old in Panyirapan Subdistrict Soreang Bandung}

\begin{abstract}
Stunting is a chronic nutritional condition caused by the intake of nutrients that are not balanced with the needs based indicator of body length for age with values exceeding <-2 Standard Deviation (SD). One of the short-term effects of stunting can affect motor development. Stunting and motor development are closely related to the quantity and quality of nutrients that are still limited so that the process of nerve development needed for motor function is disrupted. This study aims to determine the relationship of stunting with gross and fine motor development in children aged 2-5 years in Panyirapan Subdistrict, Soreang, Bandung during August-September 2019. This study was an observational analytic using a case control design with matching procedures. Subjects selected by purposive sampling technique obtained 37 samples of children for each case and control group. Gross and fine motor development was measure using Kuesioner pra-skrining perkembangan (KPSP). Stunting was measured by indicator of body length for age (Z-score) less than -2SD. Data analysis using Mc. Nemar test. The test results obtained that stunting has a possibility of 5.02 times (95\% CI: 1.46-17.11) suspected of impaired gross motor development ( $\mathrm{p}=0.013$ ), and a 6.28 times probability (95\% CI: 1.85-21.39) had suspected impairment of fine motor development compared with non-stunting $(\mathrm{p}=0.012)$. Conclusion, there is an correlation between stunting with gross and fine motor development in children aged 2-5 Years.
\end{abstract}

Keywords: Children, fine motor, gross motor, KPSP

Received: 25 January 2020; Revised: 15 July 2020; Accepted: 30 July 2020; Published: 31 July 2020

Koresponden: Citra Kartika. Program Studi Pendidikan Dokter, Fakultas Kedokteran, Universitas Islam Bandung, Jalan Tamansari No.22, 40116, Kota Bandung, Provinsi Jawa Barat, Hp : 081312416591 Email: citracika.ck@gmail.com 


\section{Pendahuluan}

Stunting merupakan masalah global yang dapat meningkatkan angka morbiditas dan mortalitas, produktivitas, serta peningkatan risiko penyakit metabolik saat dewasa. ${ }^{1}$ Definisi stunting menurut Kementerian Kesehatan (Kemenkes) adalah anak balita dengan status gizi yang dinilai berdasar atas tinggi badan menurut usia memiliki nilai $Z$-score kurang dari -2 Standar Deviasi (SD) untuk kategori pendek dan kurang dari -3SD untuk kategori sangat pendek. ${ }^{2}$ Prevalensi stunting balita di Indonesia berdasar Riset Kesehatan Dasar (Riskesdas) tahun 2018 tercatat sebesar 30,8\% terdiri atas 11,5\% sangat pendek dan 19,3\% pendek, tetapi relatif menurun dibanding dengan prevalensi pada tahun 2013 sebesar 37,2\%. ${ }^{3}$ Angka prevalensi stunting di Jawa Barat mencapai 29,2\% atau sekitar 2,7 juta. ${ }^{3}$ Kabupaten Bandung memiliki prevalensi stunting yang cukup tinggi, yaitu 38,7\% merupakan urutan kedua jumlah stunting tertinggi di Jawa Barat. ${ }^{4}$ Data survei lapangan yang dilakukan awal tahun 2019 di wilayah Kecamatan Soreang menunjukkan angka kejadian stunting tertinggi terdapat di Desa Panyirapan sebesar 15,4\%.

Berdasar atas Kementerian Kesehatan Republik Indonesia (Kemenkes RI) periode 1.000 hari pertama kehidupan merupakan periode kritis untuk menentukan kualitas kehidupan. Bila kekurangan gizi tidak ditangani selama 1.000 hari pertama kehidupan mengakibatkan stunting dan dampak krusial jangka pendek dapat terjadi salah satunya perkembangan motorik yang tidak optimal. Dua tahun pertama sangat penting untuk proses perkembangan dan arborisasi apikal dendrit korteks otak. Beberapa studi menunjukkan anak yang kekurangan gizi selama periode perkembangan otak mengalami beberapa perubahan struktural pada saraf seperti pemendekan dendrit apikal, jumlah akson berkurang, serta mengganggu proses mielinisasi yang memengaruhi kecepatan hantaran impuls antar neuron..$^{5,6}$ Beberapa komponen nutrisi yang memengaruhi fisiologis saraf adalah iron, zinc, zat besi, iodin, lemak, dan protein. ${ }^{6,7}$ Defisiensi zinc dapat mengubah arborisasi dendrit serebellar yang berkaitan dengan pengaturan koordinasi motorik. ${ }^{1}$ Fungsi motorik yang terganggu pada anak stunting berhubungan dengan kematangan otot tricep surae yang terhambat sehingga kemampuan mekanik otot terganggu. ${ }^{8}$ Menurut penelitian Hoddinot dkk. ${ }^{9}$ efek yang didapat ketika seseorang mengalami stunting adalah hambatan perkembangan motorik. Perkembangan motorik terbagi menjadi dua, yaitu motorik kasar (gross motoric) dan motorik halus (fine motoric). Motorik kasar adalah kemampuan gerak yang dikontrol oleh otot-otot besar seperti pada lengan dan kaki. Motorik halus ialah kemampuan gerak yang dikontrol oleh otot-otot kecil. ${ }^{10}$

Penelitian lain oleh Pantaleon dkk. ${ }^{11}$ di Kecamatan Sedayu, Bantul Yogyakarta didapatkan hubungan yang bermakna antara stunting dan perkembangan motorik. Sementara itu penelitian Suryaputri dkk. ${ }^{12}$ di Kelurahan Kebon Kalapa Bogor tidak terdapat hubungan antara stunting dan perkembangan motorik anak usia 2-5 tahun. Berdasar penelitian terdahulu terdapat perbedaan desain penelitian yang dilakukan. Pada penelitian ini dipergunakan desain case control karena hasil korelasi lebih tinggi dibanding dengan cross sectional. Masih terdapat perbedaan hasil antara beberapa penelitian maka mendorong peneliti melakukan penelitian hubungan stunting dengan perkembangan motorik kasar dan halus.

\section{Metode}

Penelitian ini merupakan penelitian observasional dengan desain case control yang dilakukan di Desa Panyirapan, Kec. Soreang, Kab. Bandung periode Agustus-September 2019. Subjek penelitian ini adalah anak berusia 2-5 tahun di Desa Panyirapan, Kec. Soreang yang telah sesuai dengan kriteria inklusi dan tidak termasuk kriteria eksklusi. Kriteria inklusi kelompok kasus dan kontrol adalah anak stunting dan tidak stunting usia $2-5$ tahun yang diasuh sendiri oleh ibunya serta anak kooperatif untuk dilakukan pengukuran. Kriteria eksklusi adalah anak stunting dan tidak stunting usia 2-5 tahun yang menderita penyakit bawaan yang mengganggu kemampuan motorik (cerebral palsy, meningitis, penyakit jantung bawaan, mikrosefali), mengalami trauma/fraktur, serta mengalami cacat fisik dan mental.

Penentuan besar sampel diambil dengan teknik pursposive sampling dengan prosedur matching. Berdasar atas hasil perhitungan besar subjek yang diperlukan pada penelitian adalah 37 anak untuk setiap kelompok kasus dan kontrol. Variabel bebas adalah status gizi stunting pada anak serta variabel terikat adalah perkembangan motorik kasar dan halus. Hasil status gizi stunting ditentukan berdasar atas skor-z indeks tinggi badan menurut usia <-2SD serta hasil status gizi tidak stunting bila skor-z indeks tinggi badan menurut usia lebih dari -2SD. Perkembangan anak dinilai menggunakan kuesioner praskrining perkembangan (KPSP) aspek motorik kasar dan halus berdasar atas usia. Hasil KPSP dikategorikan menjadi dua, yaitu normal dan suspek. Hasil data pelengkap karakteristik anak seperti riwayat ASI eksklusif, usia kelahiran, berat badan lahir serta data karakterisitk keluarga adalah tingkat pendidikan, pekerjaan, dan golongan pendapatan diperoleh melalui hasil wawancara. Analisis data mempergunakan program SPSS. Analisis univariat dilaksanakan untuk melihat distribusi frekuensi karakteristik responden. Analisis bivariat dilakukan untuk menilai hubungan antara variabel dependen dan independen menggunakan Uji Mc. Nemar. ${ }^{13}$

Penelitian ini sudah mendapat persetujuan etik dari Komite Etik Penelitian Kesehatan Fakultas Kedokteran Universitas Islam Bandung Nomor: 191/ Komite Etik.FK/IV/2019.

\section{Hasil}

Hasil penelitian pada Tabel 1 memperlihatkan karakteristik anak kelompok stunting dan tidak stunting mayoritas pada rentang usia $>4-5$ tahun, mendapat ASI eksklusif, berat badan lahir $\geq 2.500$ gram, dan lahir normal. 
Tabel 1 Karakteristik Anak

\begin{tabular}{lccc}
\hline \multirow{2}{*}{ Karakteristik } & \multicolumn{2}{c}{ Status Gizi } & \\
\cline { 2 - 3 } & $\begin{array}{c}\text { Stunting } \\
\mathbf{n}=\mathbf{3 7}\end{array}$ & $\begin{array}{c}\text { Tidak } \\
\text { Stunting } \\
\mathbf{n = 3 7}\end{array}$ & $\begin{array}{c}\text { Total } \\
\mathbf{n}=\mathbf{7 4}\end{array}$ \\
\hline Usia (tahun) & & & \\
$2-3$ & 9 & 9 & 18 \\
$>3-4$ & 9 & 9 & 18 \\
$>4-5$ & 19 & 19 & 38 \\
Jenis kelamin & & & \\
$\quad$ Laki-laki & 18 & 18 & 36 \\
$\quad$ Perempuan & 19 & 19 & 38 \\
ASI eksklusif & & & \\
$\quad$ Ya & 30 & 25 & 55 \\
Tidak & 7 & 12 & 19 \\
Berat badan lahir & & & \\
(gram) & & & \\
$\quad<2.500$ & 3 & 2 & 5 \\
$\quad$ 2.500 & 34 & 35 & 69 \\
$\quad$ Usia kelahiran & & & \\
Prematur & 3 & 0 & 3 \\
$\quad$ Normal & 34 & 37 & 71 \\
\hline
\end{tabular}

Tabel 2 Karakteristik Keluarga

\begin{tabular}{|c|c|c|c|}
\hline \multirow[b]{2}{*}{ Karakteristik } & \multicolumn{2}{|c|}{ Status Gizi } & \multirow[b]{2}{*}{$\begin{array}{l}\text { Total } \\
\mathrm{n}=74\end{array}$} \\
\hline & $\begin{array}{c}\text { Stunting } \\
\mathbf{n}=\mathbf{3} 7\end{array}$ & $\begin{array}{c}\text { Tidak } \\
\text { Stunting } \\
\mathbf{n}=\mathbf{3} 7\end{array}$ & \\
\hline \multicolumn{4}{|l|}{ Pendidikan ayah } \\
\hline $\mathrm{SD}$ & 11 & 10 & 21 \\
\hline SMP & 14 & 14 & 28 \\
\hline SMA & 9 & 11 & 20 \\
\hline Perguruan Tinggi & 3 & 2 & 5 \\
\hline \multicolumn{4}{|l|}{ Pendidikan ibu } \\
\hline $\mathrm{SD}$ & 10 & 11 & 21 \\
\hline SMP & 14 & 16 & 30 \\
\hline SMA & 12 & 7 & 19 \\
\hline Perguruan Tinggi & 1 & 3 & 4 \\
\hline \multicolumn{4}{|l|}{ Pekerjaan ayah } \\
\hline Buruh & 14 & 20 & 34 \\
\hline Guru & 1 & $\mathrm{O}$ & 1 \\
\hline Wiraswasta & 8 & 7 & 15 \\
\hline Konveksi & 8 & 8 & 16 \\
\hline Karyawan swasta & 2 & 2 & 4 \\
\hline Ojek & 2 & o & 2 \\
\hline PNS & 2 & $\mathrm{O}$ & 2 \\
\hline \multicolumn{4}{|l|}{ Pekerjaan ibu } \\
\hline Buruh & 3 & 1 & 4 \\
\hline Guru & 1 & O & 1 \\
\hline Wiraswasta & 2 & 2 & 4 \\
\hline Konveksi & 5 & 5 & 10 \\
\hline Perawat & 0 & 1 & 1 \\
\hline Ibu rumah tangga & 26 & 28 & 54 \\
\hline \multicolumn{4}{|l|}{$\begin{array}{l}\text { Golongan } \\
\text { penghasilan }\end{array}$} \\
\hline Rendah & 9 & 11 & 20 \\
\hline Sedang & 10 & 11 & 21 \\
\hline Tinggi & 10 & 11 & 21 \\
\hline Sangat tinggi & 8 & 4 & 9 \\
\hline
\end{tabular}

Tabel 2 memperlihatkan karakteristik keluarga meliputi pendidikan ayah, pendidikan ibu, pekerjaan ayah, pekerjaan ibu, dan golongan penghasilan orangtua. Tingkat pendidikan ayah dan ibu kedua kelompok sebagian besar tamat SMP. Pekerjaan ayah kelompok stunting dan tidak stunting mayoritas sebagai buruh. Pekerjaan ibu mayoritas bekerja sebagai ibu rumah tangga. Golongan penghasilan rendah, sedang, dan tinggi sama banyaknya antara kelompok stunting dan tidak stunting.

Berdasar atas Tabel 3 hasil penilaian aspek motorik kasar dengan penilaian suspek pada kelompok stunting sebesar 14 dari 37 anak dibanding dengan empat dari 37 anak pada kelompok status gizi tidak stunting. Hasil penilaian aspek motorik halus hasil suspek terdapat 16 dari 37 anak pada kelompok stunting dibanding dengan empat dari 37 anak pada kelompok tidak stunting.

\begin{tabular}{lccc} 
Tabel 3 & $\begin{array}{c}\text { Hasil } \\
\text { Motorik Kasar dan Halus }\end{array}$ & $\begin{array}{c}\text { Pemeriksaan } \\
\text { Karkembangan }\end{array}$ & \\
\cline { 2 - 3 } $\begin{array}{c}\text { Motorik Kasar } \\
\text { dan Halus }\end{array}$ & $\begin{array}{c}\text { Status Gizi } \\
\text { Stunting } \\
\mathbf{n = 3 7}\end{array}$ & $\begin{array}{c}\text { Tidak } \\
\text { Stunting } \\
\mathbf{n = 3 7}\end{array}$ & $\begin{array}{c}\text { Total } \\
\mathbf{n}=\mathbf{7 4}\end{array}$ \\
\hline $\begin{array}{l}\text { Motorik kasar } \\
\text { Normal }\end{array}$ & 23 & 33 & 56 \\
$\begin{array}{l}\text { Suspek } \\
\text { Motorik halus }\end{array}$ & 14 & 4 & 18 \\
$\begin{array}{l}\text { Normal } \\
\text { Suspek }\end{array}$ & 21 & 33 & 54 \\
\hline
\end{tabular}

Berdasar atas Tabel 4 dari 37 subjek yang telah di-matching-kan, pada kelompok kasus dan kontrol suspek perkembangan motorik kasar menunjukkan hubungan bermakna (signifikan) antara stunting dan tidak stunting $(\mathrm{p}=\mathrm{O}, 013)$. Hasil parameter kekuatan hubungan $\mathrm{OR}=5$,02 dengan IK 95\%: 1,46-17,21.

\begin{tabular}{|c|c|c|c|c|c|}
\hline Tabel 4 & $\begin{array}{l}\text { Hubung } \\
\text { Perkeml }\end{array}$ & $\begin{array}{l}\text { an } \\
\text { bangan }\end{array}$ & $\begin{array}{l}\text { Stunt } \\
\text { Iotorik }\end{array}$ & $\begin{array}{l}\text { ing } \\
\text { Kasar }\end{array}$ & dengan \\
\hline \multirow[b]{2}{*}{$\begin{array}{c}\text { Tidak } \\
\text { Stunting }\end{array}$} & \multicolumn{3}{|c|}{ Stunting } & \multirow{2}{*}{$\underset{\mathbf{p}^{*}}{\text { Nilai }}$} & \multirow{2}{*}{$\begin{array}{c}\text { OR } \\
\text { (IK 95\%) }\end{array}$} \\
\hline & $\begin{array}{c}\text { Suspek } \\
\mathbf{n}=14\end{array}$ & $\begin{array}{c}\text { Normal } \\
\mathbf{n}=\mathbf{2 3}\end{array}$ & $\begin{array}{l}\text { Total } \\
\mathbf{n}=\mathbf{3 7}\end{array}$ & & \\
\hline Suspek & 2 & 2 & 4 & \multirow{2}{*}{$0,013^{*}$} & 5,02 \\
\hline Normal & 12 & 21 & 33 & & $(1,46-17,21)$ \\
\hline
\end{tabular}

Keterangan: *nilai p dengan Uji Mc. Nemar

Berdasar atas Tabel 5 diketahui dari 37 subjek yang telah dilaksanakan matching pada kelompok kasus dan kontrol hasil uji statistik menunjukkan hubungan bermakna (signifikan) antara stunting dan perkembangan motorik halus $(\mathrm{p}=0,012)$. Hasil parameter kekuatan hubungan $\mathrm{OR}=6,28$ dengan IK 95\%: 1,85-21,39.

\begin{tabular}{|c|c|c|c|c|c|}
\hline \multirow[b]{3}{*}{$\begin{array}{l}\text { Tidak } \\
\text { Sunting }\end{array}$} & \multicolumn{4}{|c|}{$\begin{array}{l}\text { Hubungan Stunting } \\
\text { Perkembangan Motorik Halus }\end{array}$} & dengan \\
\hline & \multicolumn{3}{|c|}{ Stunting } & \multirow[b]{2}{*}{$-\underset{p^{*}}{\text { Nilai }}$} & \multirow[b]{2}{*}{$\begin{array}{c}\text { OR } \\
\text { (IK 95\%) }\end{array}$} \\
\hline & $\begin{array}{c}\text { Suspek } \\
\mathrm{n}=16\end{array}$ & $\begin{array}{c}\text { Normal } \\
n=21\end{array}$ & $\begin{array}{l}\text { Total } \\
\mathbf{n}=\mathbf{3 7}\end{array}$ & & \\
\hline sper & o & 4 & 4 & \multirow{2}{*}{$0,012^{*}$} & 6,28 \\
\hline Normal & 16 & 17 & 33 & & $\left(1,85^{-21,39)}\right.$ \\
\hline
\end{tabular}

Keterangan: *nilai p dengan Uji Mc. Nemar 


\section{Pembahasan}

Penelitian dilaksanakan di Wilayah kerja posyandu Desa Panyirapan, Soreang, Kab. Bandung, Jawa Barat. Mayoritas anak memiliki berat badan lahir $\geq 2.500$ gram sejalan dengan penelitian Pantaleon dkk.11 Kedua kelompok mayoritas menerima ASI eksklusif sejalan dengan penelitian Setiawan dkk. ${ }^{14}$ Hal tersebut salah satunya dapat dikaitkan dengan mayoritas pekerjaan ibu adalah sebagai ibu rumah tangga. Status pekerjaan merupakan salah satu faktor yang memengaruhi pemberian ASI eksklusif. Menurut penelitian Kurniawan dan $\mathrm{Bayu}^{15}$ pekerjaan ayah mayoritas sebagai buruh bertolak belakang dengan penelitian Probosiswi dkk. ${ }^{16}$ bahwa mayoritas bekerja sebagai wiraswasta. Perbedaan ini dikaitkan dengan perkembangan UKM meliputi perdagangan dan aneka usaha di Desa Purwomartani, Kalasan memperlihatkan kondisi yang terus meningkat sehingga memungkinkan wiraswasta menjadi pekerjaan mayoritas di desa tersebut. Pekerjaan ibu pada penelitian ini sejalan dengan penelitian Probosiswi dkk. ${ }^{16}$ serta Suryaputri dkk. ${ }^{12}$ bahwa mayoritas bekerja sebagai ibu rumah tangga. Pada penelitian kami tingkat pendidikan ayah dan ibu mayoritas berada pada jenjang tamat SMA dan SMP berbeda dari penelitian Pantaleon dkk. ${ }^{11}$ mayoritas memiliki pendidikan tinggi, yaitu lebih dari SMA. Perbedaan tersebut sesuai dengan data Badan Statistik Nasional bahwa jumlah masyarakat yang melanjutkan ke jenjang perguruan tinggi di Provinsi Yogyakarta lebih tinggi dibanding dengan provinsi lain.

Hasil perkembangan motorik kasar menunjukkan bahwa hasil suspek gangguan perkembangan motorik kasar pada anak dengan status gizi stunting lebih tinggi dibanding dengan kelompok tidak stunting. Hasil penelitian ini tidak sejalan dengan penelitian Hanani dan Syauqi ${ }^{17}$ bahwa mayoritas anak memiliki perkembangan motorik kasar yang normal. Perbedaan ini mungkin karena jumlah sampel yang relatif lebih sedikit dan hampir seluruh subjek mendapatkan stimulasi yang baik. Stimulasi yang sering diberikan dapatberpengaruh besar pada maturasi otak. Penelitian menjelaskan bahwa stimulasi dapat meningkatkan jumlah sel dendrit. Semakin banyak jumlah dendrit maka hubungan antardendrit semakin meningkat serta memengaruhi kemampuan motorik yang lebih baik. ${ }^{18}$ Perbedaan juga terdapat pada desain penelitian yang dipilih berbeda, yaitu cross sectional sehingga sampel kelompok stunting memiliki jumlah yang tidak seimbang dengan kelompok tidak stunting. Pemilihan sampel pada penelitian tersebut juga tidak dilakukan proses matching sehingga subjek pada kelompok stunting dan tidak stunting memiliki pembanding yang berbeda dari segi usia dan jenis kelamin.

Hasil perkembangan motorik halus menunjukkan bahwa hasil suspek gangguan perkembangan motorik halus pada anak dengan status gizi stunting lebih tinggi dibanding dengan kelompok tidak stunting. Hasil penelitian ini tidak sejalan dengan penelitian Hanani dan Syauqi $i^{17}$ bahwa mayoritas anak memiliki perkembangan motorik kasar yang normal. Perbedaan ini mungkin disebabkan oleh beberapa hal seperti jumlah sampel yang relatif lebih sedikit, hampir seluruh subjek mendapatkan stimulasi dari orangtua, dan desain penelitian yang dipilih berbeda. Pemilihan sampel pada penelitian tersebut juga tidak dilakukan proses matching. Namun, hasil perkembangan motorik pada penelitian ini sejalan dengan teori dan penelitian Solihin dkk. ${ }^{19}$ bahwa status gizi berkorelasi dengan kemampuan motorik. Anak dengan status gizi stunting memiliki kemampuan motorik halus yang rendah. Motorik halus yang rendah turut mengganggu aspek perkembangan motorik kasar.

Hasil uji statistik menunjukkan hubungan yang signifikan stunting dengan perkembangan motorik kasar dan halus. Hasil parameter kekuatan hubungan motorik kasar diperoleh bahwa anak dengan status gizi stunting memiliki kemungkinan lima kali suspek gangguan perkembangan motorik kasar dibanding dengan anak tidak stunting. Hasil parameter kekuatan hubungan motorik halus diperoleh bahwa anak stunting memiliki kemungkinan enam kali suspek gangguan perkembangan motorik halus dibanding dengan anak tidak stunting. Hasil penelitian ini tidak sejalan dengan penelitian Suryaputri dkk.12 Perbedaan ini mungkin disebabkan oleh metode desain penelitian yang berbeda bahwa pada penelitian tersebut menggunakan desain cross sectional, sedangkan penelitian kami menggunakan desain case control. Pengambilan sampel penelitian kami dilakukan terlebih dahulu proses matching antara kelompok kasus dan kontrol, yaitu memilih sampel yang memiliki karakteristik yang sama berdasar atas usia dan jenis kelamin. Pemilihan melalui proses matching bertujuan mengendalikan faktor perancu yang dapat memengaruhi hasil penelitian.

Hasil penelitian kami sejalan dengan penelitian Pantaleon dkk. ${ }^{11}$ serta Hanani dan Syauqy. ${ }^{17}$ Terdapat hubungan stunting dengan perkembangan motorik kasar dan halus mendukung teori bahwa anak dengan status gizi stunting memiliki kuantitas dan kualitas nutrisi yang masih terbatas sehingga terjadi perubahan struktural pada saraf seperti pemendekan dendrit apikal serta jumlah akson yang relatif berkurang. 5 Kondisi malnutrisi mengganggu aktivitas seluler sehingga menyebabkan otak tidak dapat mencapai fungsi yang optimal. ${ }^{20}$ Malnutrisi yang terjadi pada awal kehidupan dapat menyebabkan serebelum otak yang mengoordinasi gerakan motorik tergangggu. Fungsi motorik yang menurun pada anak stunting berhubungan dengan keterlambatan mekanik yang rendah pada otot tricep surae yang menyebabkan keterlambatan kematangan fungsi otot sehingga kemampuan motorik terganggu. ${ }^{8}$ Pada kondisi stunting terjadi kekurangan gizi secara kronis mengakibatkan pembentukan dan pematangan jaringan otot menjadi terhambat dibanding dengan anak status gizi normal yang memiliki otot yang kuat sehingga lebih cepat menguasai gerakan-gerakan motorik.

\section{Simpulan}

Berdasar atas penelitian yang telah dilakukan dapat disimpulkan bahwa terdapat hubungan stunting dengan perkembangan motorik kasar dan halus pada anak usia 2-5 tahun di Desa Panyirapan, Kecamatan Soreang, Kab. Bandung. 


\section{Daftar Pustaka}

1. Prendergast AJ, Humphrey JH. The stunting syndrome in developing countries. Paediatr Int Child Health. 2014;34(4):250-6.

2. Kementerian Kesehatan RI. Situasi balita pendek. Jakarta: Infodatin Kementerian Kesehatan RI; 2016.

3. Kementerian kesehatan RI. Hasil utama riskesdas 2018. Jakarta: Kementerian Kesehatan RI; 2018.

4. Kementerian Kesehatan RI. Buku saku pemantauan status gizi tahun 2017. Jakarta: Kementerian Kesehatan RI; 2017.

5. Onis M, Branca F. Childhood stunting: a global perspective. Matern Child Nutr. 2016;12:12-26.

6. Prado EL, Dewey KG. Nutrition and brain development in early life. Nutr Rev. 2014 April;72(4):267-84.

7. Stoltzfus RJ, Ngure FM, Mbuya MN, Reid BM, Pelto G, Humphrey JH. Water, sanitation, and hygiene (WASH), environmental enteropathy, nutrition, and early child development: making the links. Ann N Y Acad Sci. 2014;1308(1):118-28.

8. Paiva Md, Souza TO, Canon F, Pérot C, Xavier LC, Ferraz KM, dkk. Stunting delays maturation of triceps surae mechanical properties and motor performance in prepubertal children. Eur J Appl Physiol. 2012;112:4053-61.

9. Hoddinott J, Behrman JR, Maluccio JA, Melgar $\mathrm{P}$, Quisumbing AR, Ramirez-Zea M, dkk. Adult consequences of growth failure in early childhood. Am J Clin Nutr. 2013;98:1170-8.

10. Kementerian Kesehatan RI. Kuesioner praskrining perkembangan (KPSP). Jakarta: Kementerian Kesehatan RI; 2016.

11. Pantaleon MG, Hadi H, Gamayanti IL. Stunting berhubungan dengan perkembangan motorik anak di Kecamatan Sedayu, Bantul, Yogyakarta. J
Gizi Diietik Ind. 2015;1(3):11-9.

12. Suryaputri IY, Rosha BC, Anggraeni D. Determinan kemampuan motorik anak berusia 2-5 tahun: studi kasus di Kelurahan Kebon Kalapa Bogor. Panel Gizi Makan. 2014;37(1):43-50.

13. Sopiyudin D. Statistik untuk kedokteran dan kesehatan. Edisi ke-6. Jakarta: Salemba Medika; 2014.

14. Setiawan L, Machmud R, Masrul. Faktor-faktor yang berhubungan dengan kejadian stunting pada anak usia 24-59 bulan di wilayah kerja puskesmas Andalas Kecamatan Padang Timur Kota Padang Tahun 2018. J Kes Andalas. 2018;2(7):275-83.

15. Kurniawan, Bayu. Determinan keberhasilan pemberian air susu ibu eksklusif. J Kedok Brawijaya. 2013;27(4):236-40.

16. Probosiswi H, Huriyati E, Ismail D. Stunting dan perkembangan anak usia 12-6o bulan di Kalasan. Ber Kedokt Masy. 2017;11(33):1141-6.

17. Hanani R, Syauqy A. Perbedaan perkembangan motorik kasar, motorik halus, bahasa, dan personal sosial pada anak stunting dan non stunting. Nutr Coll. 2016;5(4):412-8.

18. Jung CKE, Herms J. Structural dynamics of dendritic spines are influenced by an environmental enrichment: an in vivo imaging study. Cereb Cortex. 2014;24 (2):377-84.

19. Solihin RDM, Anwar F, Sukandar D. Kaitan antara status gizi, perkembangan motorik pada anak usia prasekolah. J Penelit Gizi Makanan. 2013;36(1):62-72.

20. Yan X, Zhao X, Li J, He L, Xu M. Effects of earlylife malnutrition on neurodevelopment and neuropsychiatric disorders and the potential mechanisms. Prog Neuropsychopharmacol Biol Psychiatry. 2018;83:64-75. 